\title{
Siloxane Modification of Bismaleimide Resins
}

\author{
M. RAKOUTZ and M. BALME \\ Rhone-Poulenc Recherches, Centre de Recherches de Saint-Fons, \\ 69192 Saint-Fons, Cedex, France
}

(Received August 20, 1986)

\begin{abstract}
Polybismaleimides have high thermostability, but they are very brittle materials. Introduction of spacers such as aromatic diamines by addition onto the maleimide double bonds gives after crosslinking of the remaining double bonds, a polyaminobismaleimide network with greatly reduced brittleness. On this principle are based KERIMID resins and KINEL moulding powders developed by Rhone Poulenc in the early 70's. Continuing the study on toughening of bismaleimide resins, a novel concept based on their siloxane modification has been developed and it appears very promising for the formulation of hot-melt resins with tailored reactivity and easy processability by filament winding, vacuum bag moulding or injection. Thus obtained carbon fibers reinforced materials (CRFM) show good thermomechanical properties even after 40 hours ageing in boiling water or $\geqslant 1000$ hours in air at $250^{\circ} \mathrm{C}$ (more than $50 \%$ retention of the initially measured properties). Basically this type of resin is formed from bismaleimides, diphenylsilanediol and a reactive solvent. An imidazole type catalyst is added to have the desired reactivity of the system. Curing of this resin is achieved according to an epoxy type cycle and gives an opaque material with $T_{\mathrm{g}}=353^{\circ} \mathrm{C}$. This approach of polybismaleimide toughening is new, in comparison to those based on chemical linking of siloxanic units onto the polyimide chain and appears very promising for improving physical and thermomechanical properties of bismaleimide resins.
\end{abstract}

KEY WORDS Bismaleimides / Siloxanic Structures / Phase Segregation /

Toughening / Filament Winding / Vacuum Bag Moulding / Injection /

Carbon Fiber Composites /

For many years now, we have found a growing number of applications for high performance engineering polymers in different branches of the industry. Associated with a reinforcement such as current carbon fibers, composites thus obtained present high thermomechanical properties, combined with a low density.

Owing to their excellent thermal stability, polyimides are an important type of high performance polymers. Depending on the principle of the polyimide chain formation, a distinction exists between condensation type polyimides, and addition type ones.

In the former case, the polyimide structure results generally from an initially prepared polyamic acid, obtained from solution reaction between an aromatic dianhydride acid and an aromatic diamine $;^{1-8}$ further conversion of the polyamic acid to the corresponding polyimide can be achieved by chemical ${ }^{9}$ or by thermal methods ${ }^{4,10}$ (Figure 1). Thermal imidization generally involves temperatures higher than $250^{\circ} \mathrm{C}$, in order to have a convenient deshydratation. Solvent and water vapors which evolve during this treatment may create voids in the final materials, if special care is not taken. ${ }^{11}$ Another problem, associated with condensation polyimides, is their poor flow, due to their nonfusible character. ${ }^{12}$ Monitoring of the thermal deshydratation of the polyamic acid into the corresponding polyimide can be achieved using various analytical methods. ${ }^{13}$

In contrast with condensation type polyimides, addition type ones are obtained from 


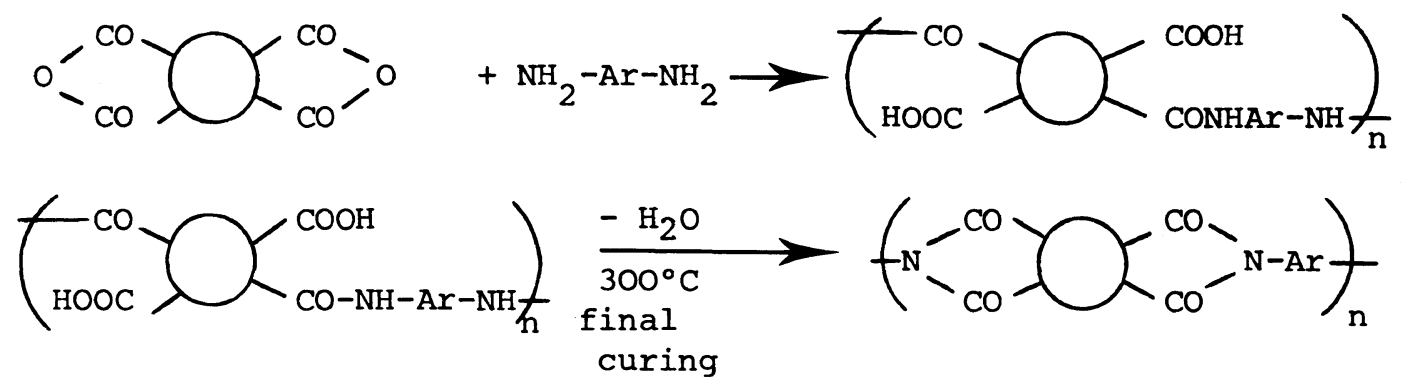

Figure 1. Chemistry of condensation type polyimides.

low molecular weight preimidized structures, which are polymerized by addition reactions or by a free radical mechanism, thus avoiding volatile formation. Flow of such type resins is determined by the length of prepolymer structures.

Resins based on this general concept have been first studied and developed by RhonePoulenc, the French firm, ${ }^{14}$ with its KERIMID (impregnation resins) and KINEL (moulding powders). According to this principle, the prepolymer resin is obtained by a MICHAEL addition, in bulk, of an aromatic diamine onto a bismaleimide, forming thus a maleimide terminated prepolymer, which easily polymerizes and crosslinks by heating (Figure 2) into a material having the following main features: - good retention of thermomechanical properties even after long ageing at $250^{\circ} \mathrm{C}$ (as shown by the Tables I and II) -absence of microcracking during thermal ageing under load

- low coefficient of thermal expansion $\left(60 \times 10^{-6} \mathrm{~m} \mathrm{~m}^{-1} \mathrm{~K}^{-1}\right)$

- good flame resistance*

-insensitivity to solvents, lubricants, aeronautic fluids like SKYDROL, cryogenic agents,

- excellent radiation resistance (up to $10^{10}$ rads**

The main application of KERIMID 601 resin is the solution impregnation of glass, quartz or aramid clothes, which are widely used in electronics for manufacturing printed circuit boards. Such prepregs are also used in aeronautics. Owing to the good processability of KINEL powders by compression, injection, or transfer moulding, the aeronautical, automotive and electrical industries have developed a large number of applications.

\footnotetext{
* Fire resistance:
}

Flammability (ASTM D-653), non flammable.

Fire resistance (French Aircraft Standard 0978/A), non flammable.

The lest is performed with a 0.09 in $(2.2 \mathrm{~mm})$ thick laminate of KERIMID 601/181 Elype glass fabric, postcured for $24 \mathrm{~h}$ at $480^{\circ} \mathrm{F}\left(250^{\circ} \mathrm{C}\right)$. The specimen is exposed horizontally onto the flame of a Mecker $=3$ burner fed with butane (flame temperature 1940 to $1960^{\circ} \mathrm{F}\left(1060\right.$ to $\left.1070^{\circ} \mathrm{C}\right)$.

There is neither striking through nor flame propagation.

The material is rated according to air: Standard 0978/A, fire proof; smoke generation, low.

** Radiation resistance:

Test were made in a Siloe nuclear reactor under a $5 \times 10^{6} \mathrm{rad} / \mathrm{h}$ flux.

Flexural strengths were measured at $77^{\circ} \mathrm{F}\left(25^{\circ} \mathrm{F}\right)$ on $1.38^{\prime \prime} \times 0.39^{\prime \prime} \times 0.06^{\prime \prime}(35 \times 10 \times 1.5 \mathrm{~mm})$ specimen: initial, $71,500 \mathrm{ps}$; after $5 \times 10^{9}$ rads, $85,500 \mathrm{ps}$.

There is no apparent alteration after at $10^{10}$ rad exposure. Laminates based on KERIMID 601 are therefore choice materials for all uses related to nuclear energy. 


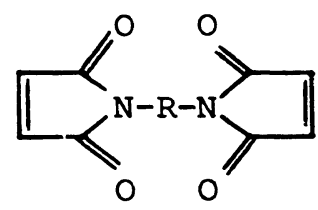

bismaleimide

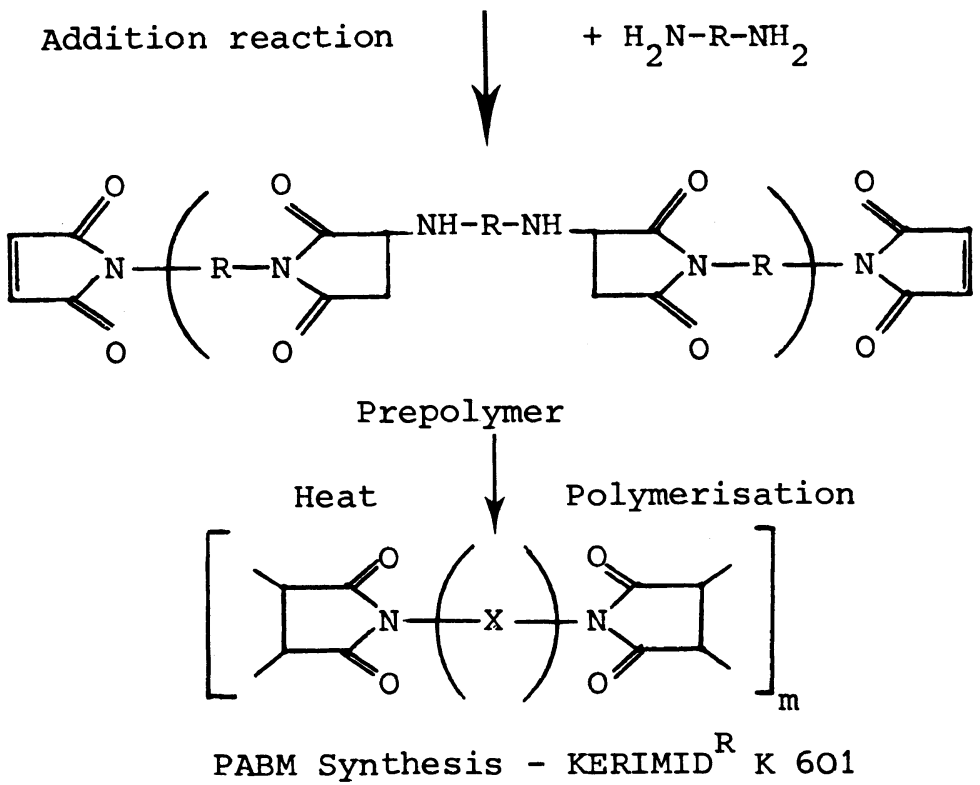

Figure 2. Chemistry of addition type bismaleimide resin.

\section{SILOXANE MODIFICATION OF BISMALEIMIDE RESINS}

The properties of a composite material depends not only on matrix and reinforcement, but also on the processing conditions. For this reason, in recent years, great interest has been shown in hot melt performances resins, which allow impregnation without solvent, thus avoiding plasticization of the polymer matrix by residual solvent, and other indesirable effects.

Continuing study of bismaleimide chemistry, Rhone-Poulenc has found an original formulation of a hot melt thermostable resin, based on bismaleimides associated with siloxane structures. ${ }^{15}$ The main characteristics of this experimental one component system are -impregnation by the hot-melt technic, or from a standard light solvent solution

- possibility to adapt the reactivity of the resin to vacuum bag moulding, filament winding or injection processing

- curing according to a thermal cycle type epoxy, not exceeding $200^{\circ} \mathrm{C}$, with a postcure at higher temperature out of the mould, in order to develop high thermomechanical properties

- good thermal ageing capability at 180 to $250^{\circ} \mathrm{C}$ for at least $2000 \mathrm{~h}$

- stable characteristics in hot and wet environment

- good compatibility with standard reinforcements, such as glass or carbon fibers. 
Table I. Mechanical properties of KERIMID $601 / 181$ E glass cloth laminates ${ }^{a}$

\begin{tabular}{|c|c|c|c|}
\hline & $\begin{array}{c}\text { ASTM } \\
\text { Standard }\end{array}$ & Unit & \\
\hline $\begin{array}{l}\text { Flexural strength } \\
\text { at } 77^{\circ} \mathrm{F}\left(25^{\circ} \mathrm{C}\right) \\
\text { at } 390^{\circ} \mathrm{F}\left(200^{\circ} \mathrm{C}\right) \\
\text { at } 480^{\circ} \mathrm{F}\left(250^{\circ} \mathrm{C}\right)\end{array}$ & $\begin{array}{c}\text { D-790 } \\
- \\
- \\
-\end{array}$ & $\begin{array}{c}\mathrm{psi} \times 10^{3} \\
- \\
- \\
-\end{array}$ & $\begin{array}{l}\text { about } 70 \\
\text { about } 60 \\
\text { about } 50\end{array}$ \\
\hline $\begin{array}{l}\text { Flexural Modulus (2) } \\
\text { at } 77^{\circ} \mathrm{F}\left(25^{\circ} \mathrm{C}\right) \\
\text { at } 390^{\circ} \mathrm{F}\left(200^{\circ} \mathrm{C}\right) \\
\text { at } 480^{\circ} \mathrm{F}\left(250^{\circ} \mathrm{C}\right)\end{array}$ & $\begin{array}{c}\text { D-790 } \\
- \\
- \\
-\end{array}$ & $\begin{array}{c}\mathrm{psi} \times 10^{3} \\
- \\
- \\
-\end{array}$ & $\begin{array}{l}\text { about } 4,000 \\
\text { about } 3,800 \\
\text { about } 3,200\end{array}$ \\
\hline $\begin{array}{l}\text { Tensile strength } \\
\text { at } 77^{\circ} \mathrm{F}\left(25^{\circ} \mathrm{C}\right)\end{array}$ & D-638 & $\mathrm{psi} \times 10^{3}$ & about 50 \\
\hline $\begin{array}{l}\text { Compressive strength } \\
\text { at } 77^{\circ} \mathrm{F}\left(25^{\circ} \mathrm{C}\right)\end{array}$ & $\begin{array}{c}\mathrm{D}-695 \\
-\end{array}$ & $\begin{array}{c}\mathrm{psi} \times 10^{3} \\
-\end{array}$ & about 50 \\
\hline $\begin{array}{l}\text { Delaminating strength } \\
\text { at } 77^{\circ} \mathrm{F}\left(25^{\circ} \mathrm{C}\right)\end{array}$ & $\begin{array}{c}\mathrm{D}-2345 \\
-\end{array}$ & psi & about 2,150 \\
\hline $\begin{array}{l}\text { Izod impact strength } \\
\text { at } 77^{\circ} \mathrm{F}\left(25^{\circ} \mathrm{C}\right) \\
\text { notched } \\
\text { unnotched }\end{array}$ & $\begin{array}{l}\text { D-256 } \\
- \\
- \\
-\end{array}$ & $\begin{array}{c}- \\
- \\
\mathrm{ft} \times \mathrm{lb} / \text { in } \\
\mathrm{ft} \times \mathrm{lb} / \text { in }\end{array}$ & $\begin{array}{l}\text { about } 13 \\
\text { about } 15\end{array}$ \\
\hline
\end{tabular}

The specimens were taken from laminates prepared in the following conditions: impregnating bath, solution of KERIMID 601 at $45 \%$ in NMP; fiberglass fabric, continuous filament yarn, satin weave of the $181 \mathrm{E}$ type with aminosilane finish; resin content in the prepreg, 30 to $35 \%$; flow rate of the prepreg, 30 to $40 \%$; stack of 12 plies; curing under 210 psi pressure ( $(15$ bars $)$ at $480^{\circ} \mathrm{F}\left(250^{\circ} \mathrm{C}\right)$ and postcuring for $48 \mathrm{~h}$ at $390^{\circ} \mathrm{F}\left(200^{\circ} \mathrm{C}\right)$, or curing under $210 \mathrm{psi}(15 \mathrm{bars})$ at $390^{\circ} \mathrm{F}\left(200^{\circ} \mathrm{C}\right)$ and postcuring for $24 \mathrm{~h}$ at $480^{\circ} \mathrm{F}\left(250^{\circ} \mathrm{C}\right)$.

\section{CHEMISTRY OF THE SILOXANE MODIFIED BISMALEIMIDE RESINS}

The basic formulation is an homogeneous blend obtained from

- Two bismaleimide monomers

4,4'-Bismaleimido diphenyl methane

Toluene bismaleimide

- Oligomerized diphenylsilanol

- Triallyl isocyanurate

- and a catalyst.

The reactivity of the resin is adjusted, in function of the desired application, by the quantity of catalyst, which is of an imidazole type. By this mean, three types of resin, each of them specifically adapted to filament winding (Fe 70003) vacuum bag moulding (Fe 70006) or injection processing (Fe 70007) have been formulated.

\section{Properties of Non Cured Resin}

Depending on the types of resin used, viscosity may range form 2000 to $10000 \mathrm{mPa} \mathrm{s}^{-1}$ at $80^{\circ} \mathrm{C}$, and from 1000 to $2000 \mathrm{mPa} \mathrm{s}^{-1}$ at $90^{\circ} \mathrm{C}$, which enables the use of hot melt processing (Figures 3 and 4).

As indicated above, the resin reactivity is controlled by the amount of catalyst. In practice, $\mathrm{Fe} 70007$ is more reactive, $\mathrm{Fe} 70003$ being the least reactive, as confirmed by their gel time values at different temperatures (Figure 5).

$\mathrm{Fe} 70003$, with a gel time of around 2 hours at $140^{\circ} \mathrm{C}$, will be more suitable for the filament winding technique. The viscosity of the melt, at $90^{\circ} \mathrm{C}$, increases from 0.7 to $0.92 \mathrm{~Pa} \mathrm{~s}^{-1}$ after 2 hours.

$\mathrm{Fe} 70006$, with a gel time of around 90 minutes at $140^{\circ} \mathrm{C}$ is particularly suitable for bag moulding. The viscosity of the melt resin, at $90^{\circ} \mathrm{C}$, increases from 1.2 to $1.7 \mathrm{~Pa} \mathrm{~s}^{-1}$ after 2 hours.

Fe 70007, with a gel time of about 25 minutes at $140^{\circ} \mathrm{C}$, is used for processing by injection moulding for single articles with high productivity. The viscosity of the melt resin, at $90^{\circ} \mathrm{C}$, increases from 1.8 to $4.9 \mathrm{~Pa} \mathrm{~s}^{-1}$ after 2 hours at this temperature.

Torsional braid analysis (Figure 6) confirm the difference in reactivity shown by the gel time values of $\mathrm{Fe} 70003$ and $\mathrm{Fe} 70006$ resins. At $200^{\circ} \mathrm{C}$, this latter gets practically the maximum of rigidity after 3 hours, compared to 10 hours needed for $\mathrm{Fe} 70003$ in the same conditions.

By differential scanning calorimetry analysis, it appears that polymerization starts from $130^{\circ} \mathrm{C}$, with the maximum of the exothermal peak at $250^{\circ} \mathrm{C}$, the enthalpy being of 
Table II. Electrical properties of $\mathrm{K} 601 / 181 \mathrm{E}$ glass cloth laminates ${ }^{\mathrm{a}, \mathrm{b}}$

\begin{tabular}{|c|c|c|c|}
\hline & Standard & Unit & \\
\hline Dielectric strength & ASTM & $\mathrm{kV} \mathrm{mm}^{-1}$ & \\
\hline initial & D-149 & - & 25 \\
\hline after $24 \mathrm{~h}$ immersion in water after ageing of: & - & - & 20 \\
\hline $1,000 \mathrm{~h}$ at $355^{\circ} \mathrm{F}\left(180^{\circ} \mathrm{C}\right)$ & - & - & $>16.5$ \\
\hline $1,000 \mathrm{~h}$ at $390^{\circ} \mathrm{F}\left(200^{\circ} \mathrm{C}\right)$ & - & - & $>16.5$ \\
\hline $1,000 \mathrm{~h}$ at $430^{\circ} \mathrm{F}\left(220^{\circ} \mathrm{C}\right)$ & - & - & 12 \\
\hline Volume resistivity & ASTM & $\mathrm{ohm} \times \mathrm{cm}$ & \\
\hline initial & D-257 & - & $6 \times 10^{14}$ \\
\hline $\begin{array}{l}\text { after } 24 \mathrm{~h} \text { immersion in water } \\
\text { after ageing of: }\end{array}$ & - & - & $1.5 \times 10^{13}$ \\
\hline $2,000 \mathrm{~h}$ at $480^{\circ} \mathrm{F}\left(250^{\circ} \mathrm{C}\right)$ & - & - & $2.2 \times 10^{15}$ \\
\hline Dielectric constant at $1 \mathrm{kHz}(1)$ & ASTM & - & \\
\hline initial & D-150 & - & 4.5 \\
\hline $\begin{array}{l}\text { after } 24 \mathrm{~h} \text { immersion in water } \\
\text { after ageing of : }\end{array}$ & - & - & 5.4 \\
\hline $10,000 \mathrm{~h}$ at $355^{\circ} \mathrm{F}\left(180^{\circ} \mathrm{C}\right)$ & - & - & 5.5 \\
\hline $10,000 \mathrm{~h}$ at $390^{\circ} \mathrm{F}\left(200^{\circ} \mathrm{C}\right)$ & - & - & 5.5 \\
\hline $10,000 \mathrm{~h}$ at $430^{\circ} \mathrm{F}\left(220^{\circ} \mathrm{C}\right)$ & - & - & 4.7 \\
\hline Dissipation factor at $1 \mathrm{kHz}$ (2) & ASTM & - & \\
\hline initial & D-150 & - & $1.2 \times 10^{-2}$ \\
\hline after $24 \mathrm{~h}$ immersion in water & - & - & $1.6 \times 10^{-2}$ \\
\hline
\end{tabular}

a Fire resistance: Fammability (ASTM D-653), non flammable; Fire resistance (French Aircraft Standard 0978/A), non flammable. The test is performed with a 0.09 in $(2.2 \mathrm{~mm})$ thick laminate of KERIMID 601/181 E type glass fabric, postcured for $24 \mathrm{~h}$ at $480^{\circ} \mathrm{F}\left(250^{\circ} \mathrm{C}\right)$. The specimen is exposed horizontally onto the flame of a Mecker $=3$ burner fed with butane (flame temperature 1,940 to $1,960^{\circ} \mathrm{F}\left(1,060\right.$ to $\left.1,070^{\circ} \mathrm{C}\right)$.

There is neither striking through nor flame propagation. The material is rated according to air: Standard 0978/A, fire proof; smoke generation, low.

b Radiation resistance: Test were made in a Siloe nuclear reactor under a $5 \times 10^{6} \mathrm{rad} / \mathrm{h}$ flux. Flexural strengths were measured at $77^{\circ} \mathrm{F}\left(25^{\circ} \mathrm{F}\right)$ on $1.38^{\prime \prime} \times 0.39^{\prime \prime} \times 0.06(35 \times 10 \times 1.5 \mathrm{~mm})$ specimen: initial, $71,500 \mathrm{ps}$; after $5 \times 10^{9} \mathrm{rads}$, $85,500 \mathrm{ps}$. There is no apparent alteration after at $10^{10} \mathrm{rad}$ exposure. Laminates based on KERIMID 601 are therefore choice materials for all uses related to nuclear energy.

\section{$-235 \mathrm{Jg}^{-1}$ (Figure 7).}

The neat resin has a good solubility, at room temperature, in such solvents as methylene chloride $(50 \%$ by weight), dichloro-1,2-ethane ( $55 \%$ by weight), and in polar aprotic solvents as NMP, DMAc, and so on. Solvents of the MEK type may be added to control evaporation of the basic solvent and thus prevent the skin effect.

\section{CURING OF THE RESINS}

Differential scanning calorimetry measurements showed that the polymerization begins at about $150^{\circ} \mathrm{C}$, with a first exothermal maximum at $200^{\circ} \mathrm{C}$ and a second one at about $250^{\circ} \mathrm{C}$ (Figure 7).

These two maxima reflect the different reactivity between the maleimide monomers on one side, and that of diphenyl silanediol and triallylisocyanurate on the other side. As a result of a complete DSC study of the system, a simple cure cycle has been defined, which is, 


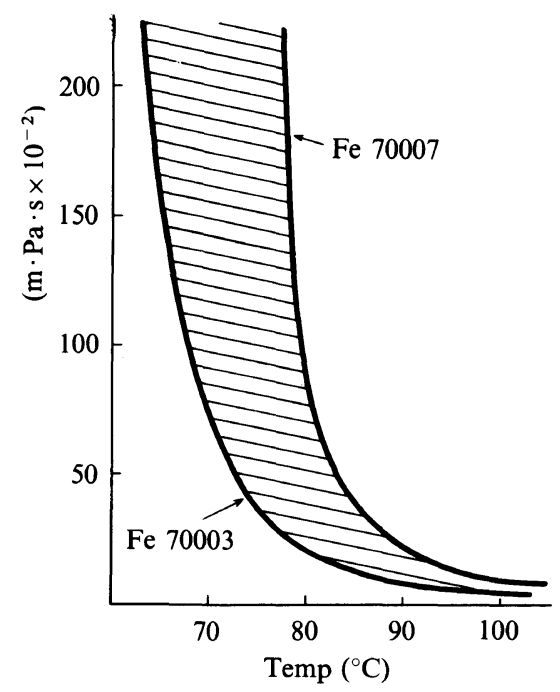

Figure 3. Viscosity of resins at different temperatures.

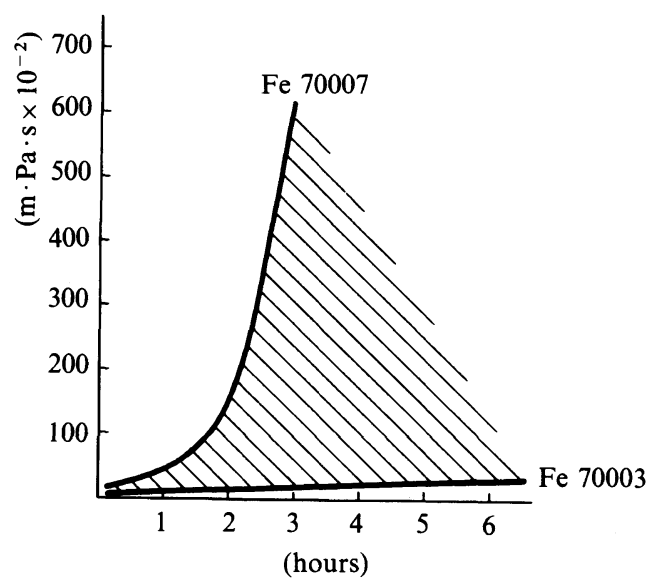

Figure 4. Vascosity change at $100^{\circ} \mathrm{C}$.

by its profile, very similar to an Epoxy type one (Figure 8).

For Fe 70006 resin, for example, the single curing cycle has been so defined:

total duration: 4-5 hours

maximum temperature: $200^{\circ} \mathrm{C}$ after a 30 minutes plateau at $150^{\circ} \mathrm{C}$

application of pressure of 7 Bars, 30 minutes after the start, held until the end of the cycle article removed from the mould for postcuring outside the mould at $250^{\circ} \mathrm{C}$ for 12 hours. Total duration of the mould immobilization

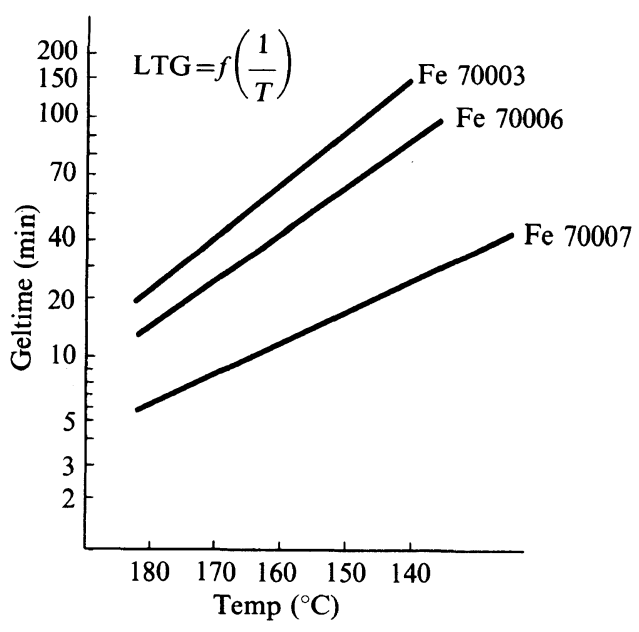

Figure 5. Gel time at various temperatures.

does not exceed 5 hours, followed then by a postcure at $250^{\circ} \mathrm{C}$, out of the mould, for 10 hours.

\section{Properties of the Cured Resin}

Although the uncured resin is an homogeneous, transparent amber-like wax, the cured material is opaque, due to a phase segregation during curing. As it can be seen by scanning electron microscopy, the cured resin has a spherulitic texture with a narrow size distribution of siloxanic spherulites of about $1.5 \mu \mathrm{m}$ in diameter (Figure 9).

Demixion of a second phase during curing of thermosetting polymers has been used for improving toughness of epoxies ${ }^{16}$ and particularly by chemically-linked siloxanic structures. ${ }^{17}$ Bismaleimides modification by addition of various amounts of a carboxyl terminated butadiene-acrylonitrile rubber leading to a morphological change has been described, ${ }^{18}$ while chemical modification of polyimides by siloxanes has been studied by other authors. ${ }^{19-21}$

The surface of fracture is covered by many very little holes or more precisely basins as they are almost spherical and do not communicate to each other. Their size is essentially uniform and the average diameter is about 


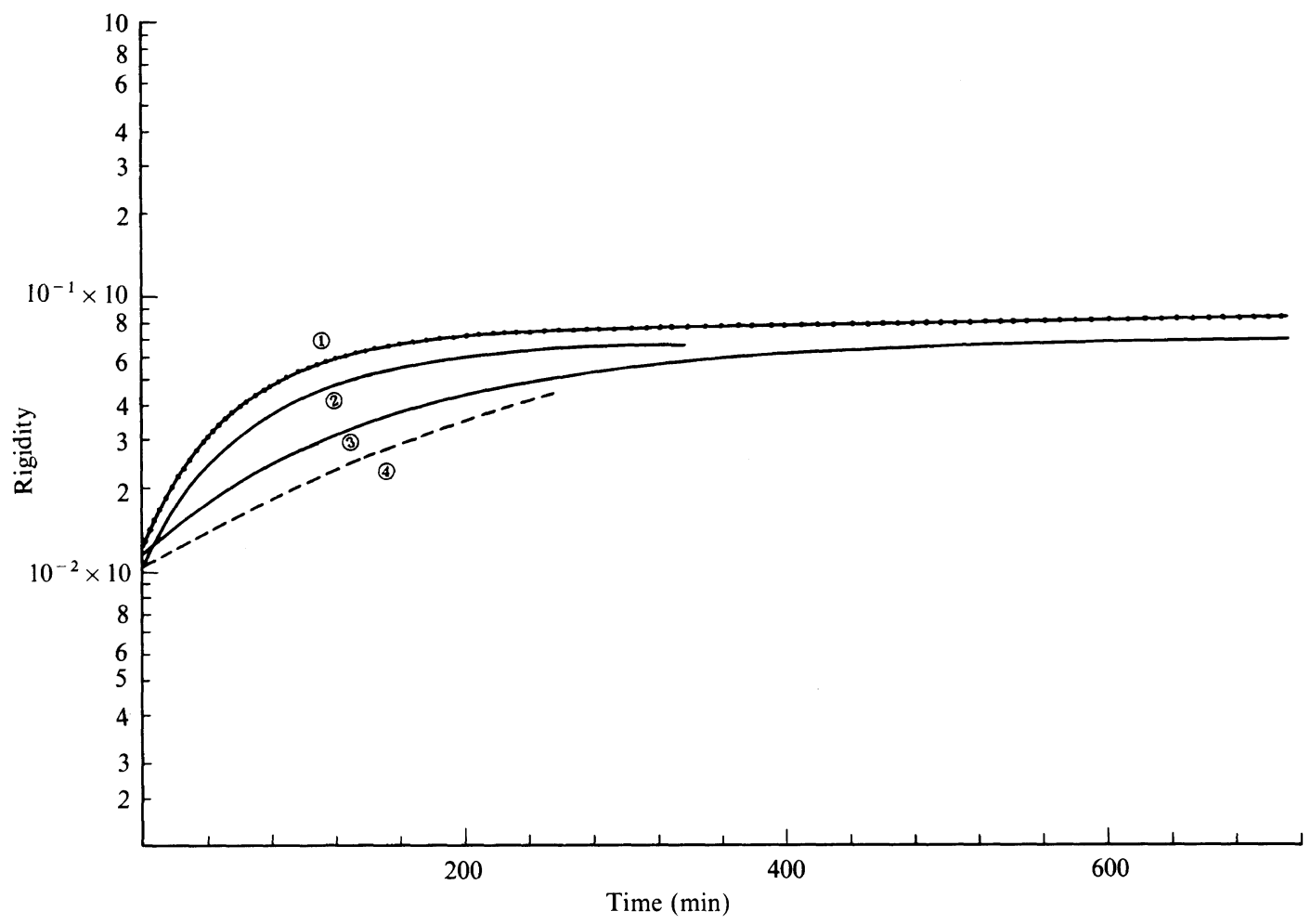

Figure 6. Torsional braid analysis curves at $200^{\circ} \mathrm{C}$ on $\mathrm{Fe} 70003$ and $\mathrm{Fe} 70006$ resins.

Deposited resin (1), $9.5 \mathrm{mg}$ FE 70006, (2), $9.0 \mathrm{mg}$ FE 70006, (3), $7.9 \mathrm{mg}$ FE 70003, (4), $8.7 \mathrm{mg}$ FE 70003.

$1.5 \mu \mathrm{m}$. The picture shown proves that these are basins and not round shaped particles. This does not exclude the possibility of a second phase.

The cavities have also been observed on fracture surfaces from almost all the other rubber-modified thermoset resins systems. ${ }^{18}$ Especially, the fracture surfaces obtained here are similar to that of an epoxy resin modified by a low molecular weight copolymer of butadiene and acrylonitrile, broken under tensile stress.

Generally, the authors attribute this surface morphology to a cavitation phenomenon occuring during the fracture itself. This induce a plastic behavior for the resin (at least locally). This plasticity has been shown with an elastomer-modified epoxy. In that case, the plasticization effect becomes higher with a decreasing crosslink density. Although all the fracture surfaces shown in these studies do not look similar, the same mechanism is always cited; it is supposed to be a blend of the following phenomena:

- toughening due to the high ductility of the elastomer,

- cavitation during crack propagation, this phenomenon being due itself to:

1. increasing in resin ductility

2. elastomer shrinkage after this fracture.

However, improvement in toughness brought about by chemical incorporation of a flexible molecular structure is usually accompanied by major reduction of other highly desirable properties, such as glass transition temperature, thermal stability, modulus, etc.

In our case the segregation of a siloxanic phase, in a crosslinked bismaleimide network, gives a tough material, compared to that of a polymerized bismaleimide without any additive. In addition, $\mathrm{Fe} 70003$ type resins show 


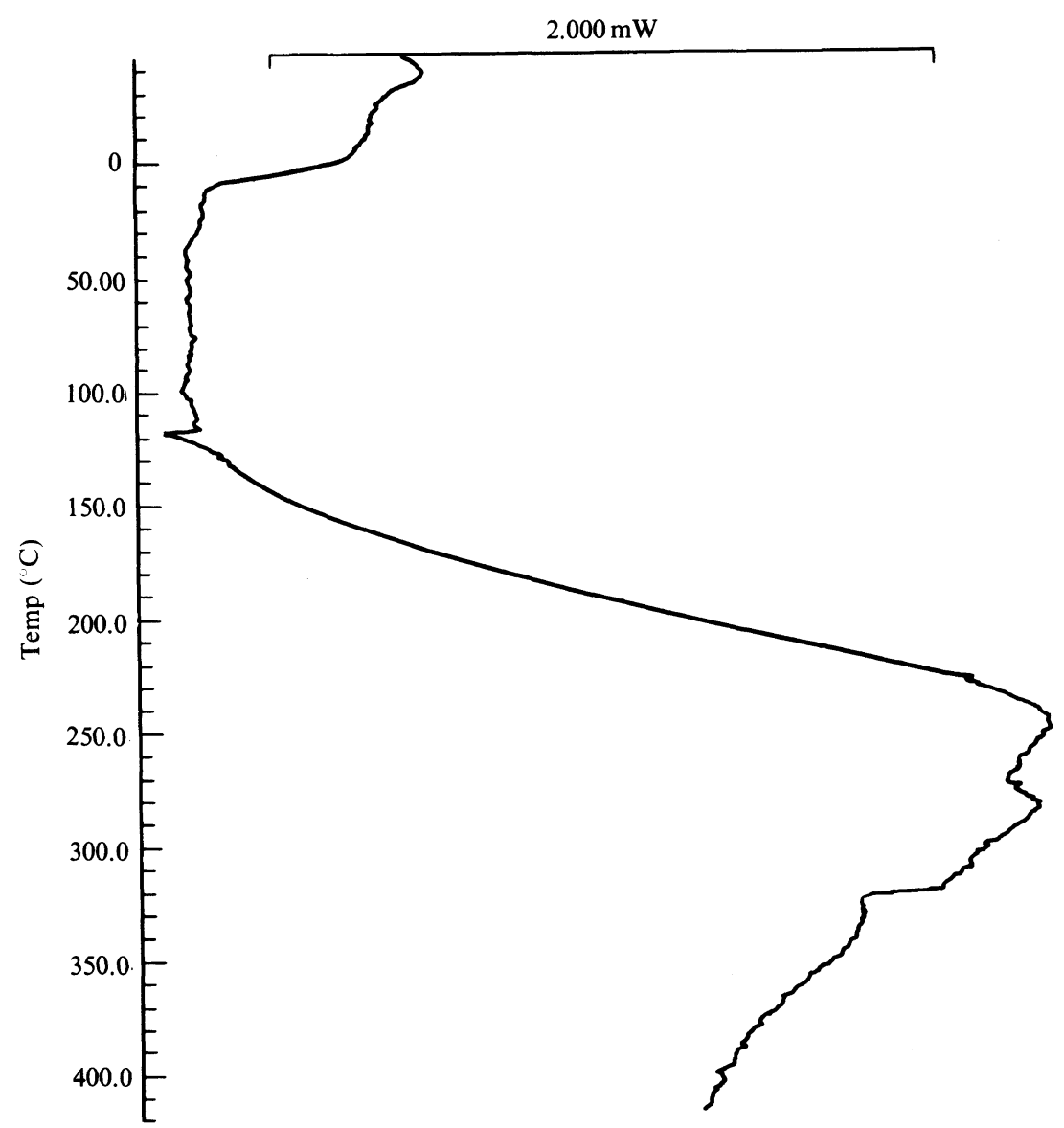

Figure 7. DSC curve of $\mathrm{Fe} 70003$ : Heating rate, $10^{\circ} \mathrm{C} \mathrm{min}^{-1}$.

high thermostability and good mechanical properties.

\section{THERMOMECHANICAL PROPERTIES}

\section{- TGA Analysis}

Thermogravimetric analysis of this polymerized resin in an air at $5^{\circ} \mathrm{C} \mathrm{min}-1$ shows a high thermostability, the half weight loss occurring only at $590^{\circ} \mathrm{C}$ (Figure 10); complete decomposition occurs at $700^{\circ} \mathrm{C}$, leaving a residue of silica.

- Besides TGA analysis, measurements of the glass transition temperature by TMA method show high values of these characteristics (Figure 11).
- The high thermal stability of this resin has been verified after 1000 hours ageing of test samples at $250^{\circ} \mathrm{C}$ in air, regarding weight loss and flexural properties:

Weight loss did not exceed $7 \%$, and no cracks have appeared on the surface of the sample (Table III).

Regarding flexural properties, no loss of the initial values was observed after the treatment, and more than $50 \%$ retention of flexural characteristics is observed (Table IV) from room temperature to $250^{\circ} \mathrm{C}$.

Some very recent results, obtained on such resins with a little modification show very interesting values:

Initially at room temperature, flexural 


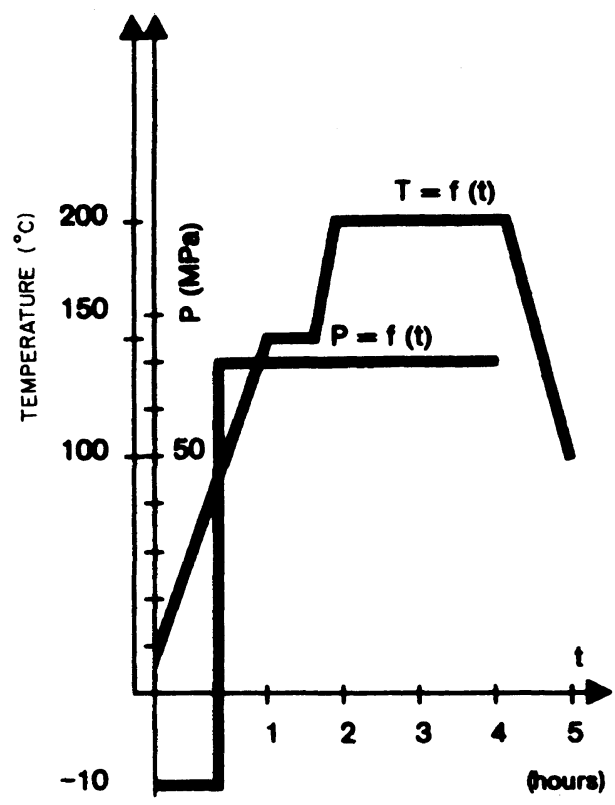

Figure 8. Cure cycle. strength is near $150 \mathrm{MPa}$ with a flexural modulus of $2700 \mathrm{MPa}$.

At $250^{\circ} \mathrm{C}$, flexural strength is $80 \mathrm{MPa}$ with a flexural modulus of $1800 \mathrm{MPa}$.

After an ageing of 1000 hours at $250^{\circ} \mathrm{C}$ : flexural strength at room temperature is

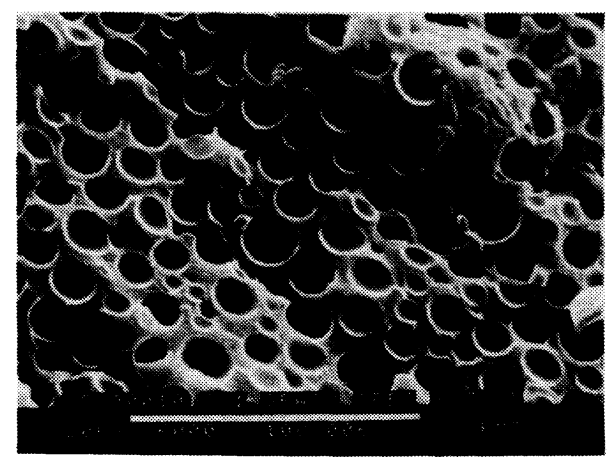

Figure 9. A spherulitic texture of the cured resin by SEM.

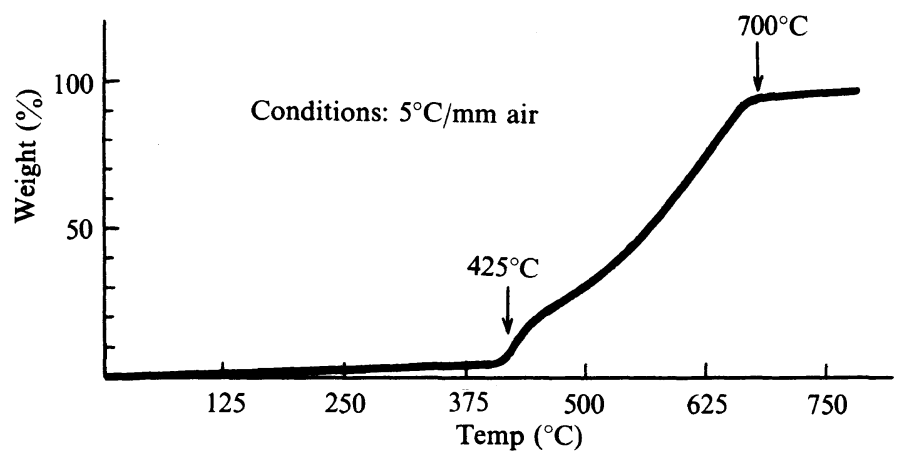

Figure 10. Thermogravimetric analysis. of $\mathrm{Fe} 70003$.

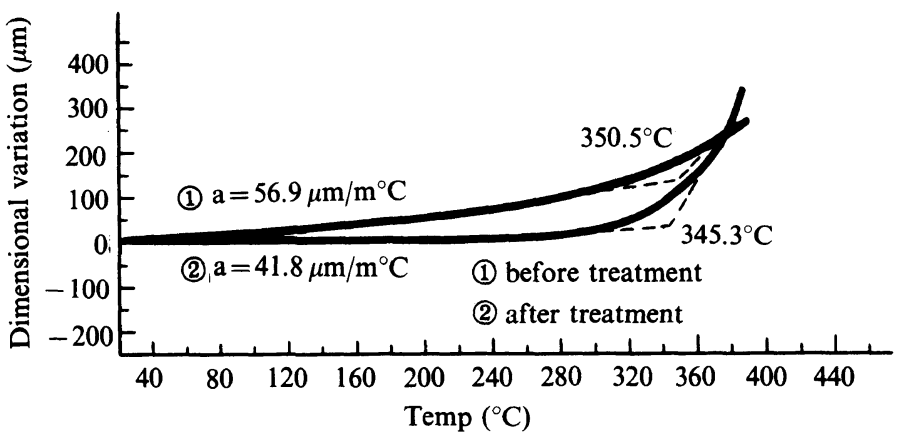

Figure 11. TMA on Fe 70003 cured resin: (1) dry resin; (2) after $100 \mathrm{~h}$ in boiling water. 
$110 \mathrm{MPa}$ and flexural modulus $2900 \mathrm{MPa}$. Flexural strength at $250^{\circ} \mathrm{C}$ is $60 \mathrm{MPa}$ and modulus $2300 \mathrm{MPa}$.

Regarding compression properties, some values are available, and we can observe an important deformation before damage on Fe 70003 (Table V).

- In order to evaluate more fully the advantages of this new system, influence of hot wet environment on the physical properties of the matrix has been determined too. It is well known that in the case of epoxy resins, water absorption greatly decreases other characteristics, such as glass transition temperature. ${ }^{22}$

Immersion of $\mathrm{Fe} 70003$ type resins in boiled water during 100 hours indicates an absorption of 1.5 to $2 \%$ by weight. But, contrarily to epoxy resins, this absorbed water does not induce any appreciable modification of the

Table III. Weight loss after $1000 \mathrm{~h}$ at $250^{\circ} \mathrm{C}$

\begin{tabular}{cc}
\hline Fe 70003 & $7 \%$ \\
\hline Fe 70006 & $5 \%$ \\
\hline Fe 70007 & $4,6 \%$ \\
\hline
\end{tabular}

Sample: $30 \times 7 \times 4 \mathrm{~mm}$. No cracks after ageing test. glass transition temperature (Figure 11).

- The critical intensity factor $K_{1} C$ has been determined a value of $0.52 \mathrm{MPa} \sqrt{m}$ is obtained for neat $\mathrm{Fe} \mathrm{70006.} \mathrm{Elongation} \mathrm{of} \mathrm{these}$ resins is around $2 \%$. More work has been performed toward improving these crucial properties, and the latest resins look promising.

\section{Properties of Carbon Fiber Composites}

As reported here, the more convenient formulation for vacuum bag moulding of composite materials is the $\mathrm{Fe} 70006$ one. Because carbon fibers produce optimal results with polymer matrix needed by the aerospace industries, some unidirectional 28 plies composites have been prepared, using AS4H carbon fibers.

Measurements of thermomechanical properties at $250^{\circ} \mathrm{C}$ show good retention of these values, compared to the corresponding one, obtained at room temperature. For example, one has $50 \%$ retention in interlaminar shear strength, $60 \%$ in flexural strength and $90 \%$ in flexural modulus (Table VI). After ageing $1000 \mathrm{~h}$ at $250^{\circ} \mathrm{C}$, in air, no noticeable change of the ILSS value is observed (Table VI), neither after 40 hours in boiled water.

Table IV. Flexural properties of the neat resin after $1000 \mathrm{~h}$ ageing at $250 \mathrm{C}$

\begin{tabular}{|c|c|c|c|c|c|c|c|c|}
\hline \multirow{2}{*}{$\begin{array}{l}\text { Type of } \\
\text { resin }\end{array}$} & \multicolumn{2}{|r|}{$\begin{array}{l}20^{\circ} \mathrm{C} \\
\quad(\mathrm{MPa})^{\mathrm{a}}\end{array}$} & \multicolumn{2}{|r|}{$250^{\circ} \mathrm{C}$} & \multicolumn{2}{|r|}{$20^{\circ} \mathrm{C}$} & \multicolumn{2}{|r|}{$250^{\circ} \mathrm{C}$} \\
\hline & Initial & $\begin{array}{l}\text { After } 1000 \mathrm{~h} \\
\text { at } 250^{\circ} \mathrm{C}\end{array}$ & Initial & $\begin{array}{l}\text { After } 1000 \mathrm{~h} \\
\text { at } 250^{\circ} \mathrm{C}\end{array}$ & Initial & $\begin{array}{l}\text { After } 1000 \mathrm{~h} \\
\text { at } 250^{\circ} \mathrm{C}\end{array}$ & Initial & $\begin{array}{l}\text { After } 1000 \mathrm{~h} \\
\text { at } 250^{\circ} \mathrm{C}\end{array}$ \\
\hline Fe 70003 & 59 & 52 & 36 & 13 & 1790 & 2660 & 1100 & 1500 \\
\hline Fe 70006 & 74 & 81 & 42 & 46 & 1690 & 2150 & 1100 & 1400 \\
\hline
\end{tabular}

a ASTM D 790-71.

Table V. Compression strength of $\mathrm{Fe} 70003$ initial values after postcure at $250^{\circ} \mathrm{C}$ (neat resin)

\begin{tabular}{cccc}
\hline $\begin{array}{c}\text { Temperature } \\
\text { measurement }\end{array}$ & $\begin{array}{c}\text { Compression } \\
\text { strength (MPa) }\end{array}$ & $\begin{array}{c}\text { Modulus of elasticity } \\
\text { in compression (MPa) }\end{array}$ & $\begin{array}{c}\text { Ultimate } \\
\text { strain (\%) }\end{array}$ \\
\hline $20^{\circ} \mathrm{C}$ & 300 & 1680 & 30 \\
$220^{\circ} \mathrm{C}$ & 100 & 1200 & 300 \\
\hline
\end{tabular}


Table VI. Mechanical properties of an UD composite from Fe 70006/AS $4 \mathrm{H}$ carbon fibers $(37 \%$ by weight of resin)

\begin{tabular}{|c|c|c|c|c|c|c|c|c|}
\hline & \multirow{2}{*}{\multicolumn{2}{|c|}{$\begin{array}{c}\text { Flexural strength } \\
\mathrm{MPa}\end{array}$}} & \multirow{2}{*}{\multicolumn{2}{|c|}{$\frac{\text { Flexural modulus }}{\mathrm{MPa}}$}} & \multicolumn{4}{|c|}{$\operatorname{ILSS}(\mathrm{MPa})^{\mathrm{a}}$} \\
\hline & & & & & \multicolumn{2}{|c|}{ Initially } & \multicolumn{2}{|c|}{$\begin{array}{l}\text { After } 1000 \mathrm{~h} \\
\text { at } 250^{\circ} \mathrm{C}\end{array}$} \\
\hline \multirow[t]{3}{*}{$\begin{array}{c}\text { Temperature } \\
\text { of measurement }\end{array}$} & $20^{\circ} \mathrm{C}$ & $250^{\circ} \mathrm{C}$ & $20^{\circ} \mathrm{C}$ & $250^{\circ} \mathrm{C}$ & $20^{\circ} \mathrm{C}$ & $250^{\circ} \mathrm{C}$ & $20^{\circ} \mathrm{C}$ & $250^{\circ} \mathrm{C}$ \\
\hline & 860 & 540 & 84,000 & 79,700 & 55 & 28 & 40 & 30 \\
\hline & \multicolumn{4}{|c|}{ After $40 \mathrm{~h}$ in boiling water } & & 26 & & \\
\hline
\end{tabular}

a ASTM D 2344-76.

Our present research allows good hopes to obtain much higher values of interlaminar shear strength above $100 \mathrm{MPa}$.

In addition, as indicated by interlaminar shear strength measurements and electron microscopy examination of the fracture of UD carbon fiber composite parts treated 40 hours in boiled water, there is no appreciable damage either of the polymeric matrix itself, or of the fiber/matrix interface (Table VI).

\section{CONCLUSION}

The preliminary results obtained on this new type of hot melt, aromatic diamine-free, bismaleimide resins show that a reasonable level of toughness can be reached, owing to the siloxane phase separation during cure. By this way, the main properties of the bismaleimide matrix are preserved, combined with an easy processability, similar to that of epoxy resins. Current studies of this new system indicate the wide possibilities of such modification type leading to an increase of the general mechanical characteristics.

Even more promising, up-to-date resins are now being studied. ${ }^{23}$

\section{REFERENCES}

1. W. Volksen and P. M. Cotts, "Polyimides," Vol. 1, K. L. Mittal, Ed., Plenum Press, New York, 1984, p 163.
2. R. L. Kass, J. Polym. Sci., Polym. Chem. Ed., 19, 2255 (1981).

3. M. M. Koton, V. V. Kudriatsev, and V. M. Svetlichny, "Polyimides," Vol. 1, K. K. Mittal, Ed., Plenum Press, New York, 1984, p 171.

4. S. V. Vinogradova, Y. S. Vygodski, T. N. Spirina, L. I. Chudina, and V. V. Korshak, Polym. Sci., USSR, 21, 1166 (1979).

5. V. L. Bell, B. L. Stump, and H. Gager, J. Polym. Sci., Polym. Chem. Ed., 14, 2275 (1976).

6. T. L. Saint-Clair and D. J. Progar, Polym. Prepr., Am. Chem. Soc., Div. Polym. Chem., 16, 538 (1975).

7. G. M. Bower and L. W. Frost, J. Polym. Sci., A-1, 3135 (1963).

8. C. E. Sroog, J. Polym. Sci., Macromol. Rev., 11, 161 (1976).

9. S. V. Vinogradova, Y. S. Vygodski, V. D. Vorobiev, N. A. Shurakhina, L. I. Chudina, T. N. Spirina, and V. V. Korshak, Polym. Sci., USSR, 16, 584 (1974).

10. J. Kreuz, A. L. Endrey, F. P. Gay, and C. E. Sroog, J. Polym. Sci., A-1, 4, 2607 (1966).

11. T. T. Serafini, Handbook of Fiberglass and Advanced Plastics Composites, G. Lubin, Ed., van Nostrand Reinhold Company, 1969.

12. F. A. Bystry-King and J. J. King, "Engineering Thermoplastics. Properties and Applications," J. M. Margolis and M. Dekker, Ed., 1985, p 323.

13. J. F. Dezern and P. R. Young, Int. J. Adhesion Adhesives, 5, 183 (1985).

14. Rhône-Poulenc, BF 1,115,564 was firstly published in France $(23 / 12 / 68)(\equiv \mathrm{JA} 632,431)$.

15. Rhône-Poulenc, BF 2,553,780 was firstly published in France $(26 / 04 / 85)$ ( Japan Patent Kokai Number 85/110,713).

16. A. J. Kinloch, S. J. Shaw, and D. L. Hunston, Polymer, 24, 1355 (1983).

17. E. M. Yorkgitis, N. S. Eiss, C. Tran, G. L. Wilkes, and J. E. McGrath, Adv. Polym. Sci., 72, 80 (1985).

18. S. J. Shaw and A. J. Kinloch, Int. J. Adhesion Adhesives, 5, 123 (1985). 
19. B. C. Johnson, J. L. Hedrich, F. Campbell, and J. E. McGrath, Proceedings, 29th National SAMPE Symposium, April, 1984, p 447.

20. Hong Song Ryang, German Patent to General Electric, $n^{\circ} 3,341,700 A_{1}$ 11/18/1982.

21. S. Maugdal and T. L. Saint-Clair, SAMPE Quarterly
24 (April 1984).

22. A. Apicella and L. Nicolais, Adv. Polym. Sci., 72, 69 (1985).

23. J. Seferis and Lopez, SAMPE Quarterly, in press (1986). 